\title{
Back on the map
}

\author{
Central and eastern European nations still lag behind Western countries \\ in science. But they are slowly catching up.
}

T wenty years after the end of Soviet communism, many of the former satellite states in central and eastern Europe have joined the West as members of the European Union (EU). Yet by many measures, the science being done in those states still lags behind. Not only do their overall public and private scientific expenditures tend to be lower than those of their EU partners, as are their levels of participation in EU-funded research collaborations, but their very academic structures also remain a barrier to international competitiveness.

This is not to say that nothing has happened since 1989 - a year in which the fall of the Berlin Wall was paralleled by the near-collapse of academic and industrial science throughout the former Eastern bloc. The former German Democratic Republic, for example, has now caught up with the rest of western Europe owing to massive investment after the reunification of Germany in 1990. And the small Baltic country of Estonia, which spent that same period overhauling its Soviet-style academic structures and introducing a modern funding system based on grants, publications and peer review, has become a poster child for successful transition to Western-style science. Today it boasts considerable strengths in material, biomedical and environmental technologies.

But elsewhere, the academic hierarchy has often proved more resistant to change. Granted, countries including Hungary, Slovenia, the Czech Republic and Poland have seen the emergence of excellent research groups and institutes, many of them led by scientists who graduated around 1989 and were quick to grasp the opportunity to leave and gather experience abroad (see page 586). The International Institute of Molecular and Cell Biology in Warsaw, set up in 1999 with support from the United Nations Educational, Scientific and Cultural Organization (UNESCO), is a prominent example.

With the exception of Estonia, however, basic research in the region is still controlled by the national academies of science: governmentfunded organizations that independently operate numerous research institutes. Most of these academies have undergone evaluations of their respective strengths and weaknesses over the past decade, with the result that some of the least-productive institutes have been closed or restructured. And the knee-jerk opposition to the 'Westernization' of science is rapidly declining, as is political resentment and antiWestern ideology in general. Still, not all of these academy institutes are as well connected to the outside world of science as they should be. Young scientists there have good reason to complain about academic hierarchies whose existence is unjustified by scientific merit, and about funding channels that fail to reward the best research proposals.

Addressing their complaints will require the reinforcement of merit-based science in central and eastern Europe, which in turn will require that scarce resources are
"Science has from the flow of talent from eastern Europe and Russia." benefited greatly focused on existing and emerging strengths. The current economic crisis must not lead to a lasting decline in funding for science and higher education, either in Hungary, which has been hit particularly hard, or elsewhere in the region. The various national labs and institutions should reward mobility more than they have done in the past, as any upswing in their own scientific establishments will require that as many students and young scientists as possible gain experience in the best labs abroad. Finally, the region would gain substantial prestige and visibility if a large multinational research facility, such as the planned European Spallation Source, were to be built in one of the new EU member states.

Globally, science has benefited greatly from the flow of talent from eastern Europe and Russia over the past 20 years. That brain drain has not made the transition at home any easier. Although it has taken more time than anticipated to put central and eastern Europe back on the global map of science, the upcoming generation of young, energetic students and scientists should be able to complete the process. It would be to everybody's gain. The heart of Europe deserves good science, but the rest of the world needs good science from this culturally rich region just as much.

\section{Containing risk}

\section{The US Department of Homeland Security should not be put in charge of biodefence research.}

T he past few months have brought a rich harvest of high-level reports on US biosecurity, with a particular focus on the nearly 1,400 American labs known to be doing research on human, plant and animal pathogens risky enough to require special containment. The reports were largely inspired by the announcement from the US Federal Bureau of Investigation in August 2008 that Bruce
Ivins, a senior researcher at the US Army Medical Research Institute of Infectious Diseases in Fort Detrick, Maryland, was considered to be the "sole culprit" in the deadly 2001 anthrax attacks. Several of the reports - two of them issued last week - recommend that a single agency be put in overall charge of what is now a fragmented oversight system involving at least a dozen agencies. Their laudable goal is to tighten the safeguards against biological threats, including any that might emanate from within the labs, without stifling research on countermeasures against any future attacks.

As always, however, the devil lies in the details. Witness the Weapons of Mass Destruction Prevention and Preparedness Act of 2009 (see page 577), a bill introduced in the Senate last month by the two 